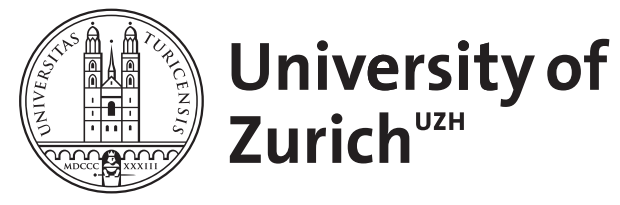
Archive

University of Zurich

University Library

Strickhofstrasse 39

CH-8057 Zurich

www.zora.uzh.ch

Year: 2008

The neutral protease chymase degrades apolipoprotein E from high-density lipoproteins

Lee-Rueckert, M ; von Eckardstein, A ; Kovanen, P T

DOI: https://doi.org/10.1515/CCLM.2008.072

Posted at the Zurich Open Repository and Archive, University of Zurich ZORA URL: https://doi.org/10.5167/uzh-5390

Journal Article

Published Version

Originally published at:

Lee-Rueckert, M; von Eckardstein, A; Kovanen, P T (2008). The neutral protease chymase degrades apolipoprotein E from high-density lipoproteins. Clinical Chemistry and Laboratory Medicine, 46(3):421423.

DOI: https://doi.org/10.1515/CCLM.2008.072 


\section{The neutral protease chymase degrades apolipoprotein $E$ from high-density lipoproteins}

\author{
Miriam Lee-Rueckert ${ }^{1}$, Arnold von Eckardstein ${ }^{2}$ \\ and Petri T. Kovanen ${ }^{1, *}$ \\ ${ }^{1}$ Wihuri Research Institute, Helsinki, Finland \\ 2 Institute for Clinical Chemistry, University Hospital \\ Zurich, Zurich, Switzerland
}

Keywords: apolipoprotein E; chymase; high-density lipoprotein; mast cells; reverse cholesterol transport.

High-density lipoproteins (HDL) encompass a heterogeneous class of lipoproteins in which apolipoprotein (apoA)-I predominates. Although concentrations of HDL with apoE are low in humans, apoE in HDL was found to facilitate efflux of cholesterol from macrophages, HDL particle growth and delivery of HDL-cholesterol to the liver (1). Similar to apoA-I, interaction of apoE with the transmembrane protein ABCA1 leads to formation of HDL-like particles (2). Of note, secretion of apoE by macrophages is stimulated by apoA-I representing a positive feedback process to potentiate the cholesterol-efflux inducing capacity of extracellular fluid (3). Moreover, apoE-rich $\mathrm{HDL}_{2}$ particles are efficient cholesterol acceptors via the ABCG1 pathway in macrophages (4).

Chymase is a neutral serine protease produced by mast cells and stored in their cytoplasmic secretory granules. The enzyme has been detected in mast cells located in the human arterial intima, the site of atherogenesis (5). Upon stimulation, the activated mast cells exocytose a fraction of their secretory granules. While histamine is released from the granules, chymase remains tightly bound to the heparin glycosaminoglycan chains in the formed "granule remnants" and remains partially active in the presence of its physiologic inhibitors found in plasma (6). Due to its broad substrate specificity, chymase may act on various protein components of the extracellular fluid and the pericellular matrices (7). We have found that chymase is able to efficiently degrade apoA-I and apoA-IV, and less efficiently apoA-II, as well as other components of the reverse cholesterol transport present in human plasma, such as the phospholipid transfer protein (8).

Given the role of apoE in the reverse cholesterol transport, we investigated whether mast cell-derived

*Corresponding author: Petri T. Kovanen, Wihuri Research Institute, Kalliolinnantie 4, 00140 Helsinki, Finland

Phone: +358-9-681411, Fax: +358-9-637476,

E-mail: petri.kovanen@wri.fi chymase is able to degrade apoE in HDL particles. Because apoE is involved in the development of hypertriglyceridemia in humans, and circulating apoE levels have been shown to increase in hypertriglyceridemic (HTG) patients (9), blood samples were obtained from two HTG subjects (Helsinki University Hospital) after overnight fasting. Blood was drained into pre-cooled tubes containing Kabikinase at a final concentration of $150 \mathrm{IU} / \mathrm{mL}$ of blood. Plasma was obtained by centrifuging blood at $4^{\circ} \mathrm{C}$ for $30 \mathrm{~min}$ and kept at $-70^{\circ} \mathrm{C}$ until analyzed. We used as the source of chymase the granule remnants isolated from rat serosal mast cells. Importantly, both rat and human chymase cleave apoA-I in pre $\beta$-migrating HDL and generate identical proteolytic patterns (10).

First, we evaluated the ability of granule remnants to proteolyze HDL in control plasma obtained from normolipidemic subjects by adding ${ }^{125}$-labeled HDL to the incubation mixtures and measuring the production of ${ }^{125}$-labeled TCA-soluble degradation products. For that, $50 \%$ of plasma (i.e., diluted with buffer) was treated with $30 \mu \mathrm{g}$ of chymase-containing granule remnants at $37^{\circ} \mathrm{C}$ for $1 \mathrm{~h}$ and $6 \mathrm{~h}$, respectively. Incubation was stopped by centrifugation at $4^{\circ} \mathrm{C}$, $10,000 \mathrm{rpm}(8900 \times \mathrm{g})$ for $5 \mathrm{~min}$ to sediment the granule remnants. Under these conditions chymase degraded $2.2 \%$ and $3.7 \%$ of the ${ }^{125}$-labeled apolipoproteins present in HDL. Next, we evaluated by Western blotting the distribution of apoE- and apoA-Icontaining lipoproteins (designated as LpE and LpA-I, respectively) in such incubation mixtures. Figure 1 shows representative results of two-dimensional polyacrylamide gradient gel electrophoresis (first and second dimension as indicated by arrows) analyses of LpE (panels A-D) and LpA-I (panels E-H) of plasma from subject 1 (Table 1) after treatment with chymase. In the control (non-treated) plasma, apoE was associated to particles having either $\beta$ - or $\alpha$-electrophoretic mobility in the first dimension, and various mobilities in the second dimension reflecting heterogeneous particle sizes (panel A). Compatible with previous findings (11), $\alpha-L p E$ co-migrated with $\alpha$-LpA-I (compare panels A and E). Importantly, incubation of plasma for $1 \mathrm{~h}$ with mast cell granules was sufficient to degrade apoE in all HDL subpopulations, independently of their electrophoretic mobility and sizes (panel B). Also, practically all of pre $\beta_{1}$ LpA-I particles, known for their high sensitivity to chymase degradation (12), were degraded during this short time of incubation with chymase (panel F). In sharp contrast, only minor degradation of $\alpha$-LpA-I by chymase was achieved even after the longest incubation 


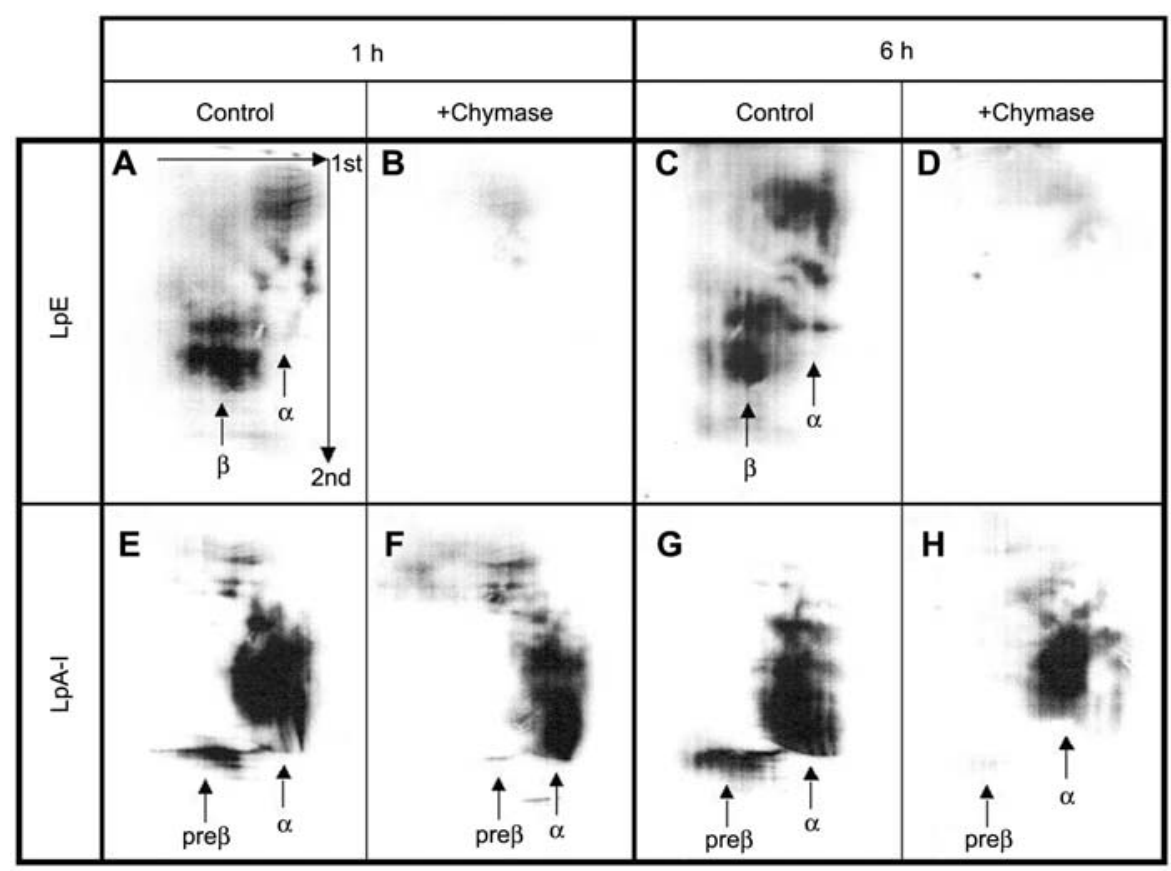

Figure $1 \mathrm{ApoE}$ - and apoA-I-containing lipoproteins before and after treatment of plasma with the neutral protease chymase. Plasma $(30 \mu \mathrm{L})$ was incubated with chymase for $1 \mathrm{~h}$ and $6 \mathrm{~h}$ at $37^{\circ} \mathrm{C}$ in the absence or presence of $30 \mu \mathrm{g}$ of chymasecontaining granule remnants (40 BTEE units) in $60 \mu \mathrm{L}$ of $5 \mathrm{mM}$ Tris- $\mathrm{HCl}$ containing $150 \mathrm{mM} \mathrm{NaCl}, 1 \mathrm{mM}$ EDTA, pH 7.4 . Incubation was terminated by centrifuging the vials at $10,000 \mathrm{rpm}(8900 \times \mathrm{g})$ to sediment the granule remnants, and the supernatant was kept at $-70^{\circ} \mathrm{C}$ until analysis. Aliquots $(40 \mu \mathrm{L})$ of the incubation mixtures were separated by two-dimensional electrophoresis in the sequence agarose gel electrophoresis $\rightarrow$ non-denaturing polyacrylamide gradient gel electrophoresis. After electroblotting to a nitrocellulose membrane, apoE- and apoA-I-containing particles were detected with polyclonal antisera against human apoE or apoA-I and horseradish peroxidase-conjugated second antibodies, as previously described (11).

Table 1 Characteristics of subject 1.

\begin{tabular}{ll}
\hline Gender & Male \\
\hline Age, years & 67 \\
Total cholesterol, mmol/L & 5.6 \\
LDL cholesterol, mmol/L & 2.91 \\
$\mathrm{HDL}$ cholesterol, $\mathrm{mmol} / \mathrm{L}$ & 0.89 \\
Triglycerides, mmol/L & 3.92 \\
Lipid medication & None \\
\hline
\end{tabular}

time (panel H). Similar results were obtained with plasma of subject 2 (data not shown). The degradation of apoE in $\alpha$-migrating HDL found here could partly explain why chymase strongly impairs the ability of mature HDL to act as cellular cholesterol acceptor, despite that only a low degree of apoA-I proteolysis is achieved (13).

In addition to mast cells, human atherosclerotic lesions contain endothelial cells, smooth muscle cells and inflammatory cells, such as macrophages and T lymphocytes that also secrete proteases into the inflammatory intima. Recently, apoA-I breakdown products and selective pre $\beta-\mathrm{HDL}$ degradation have been found in the circulation of patients with acute myocardial infarction (14). This finding supports the notion that extracellular proteolysis may occur in conditions of protease burden likely to be present in the inflamed intima. Importantly, the gain in resistance of mast cell-derived chymase against the serpins by its association with the heparin proteoglycans of the mast cell granules (6) strongly suggests that chymase may be one of the intimal proteases capable of degrading HDL in vivo in the extracellular fluid of the intima. As HDL particles in human atherosclerotic lesions are enriched in apoE (15), we conclude that extracellular proteolysis of apoE-containing $\mathrm{HDL}$ is a novel inhibitory principle that may interfere with the initiation of reverse cholesterol transport in the atherosclerotic arterial intima.

\section{Acknowledgements}

This work was supported by the Sigrid Juselius Foundation (M.L.-R.) and the Swiss National Fund (A.v.E.). The Wihuri Research Institute is maintained by the Jenny and Antti Wihuri Foundation. The authors thank Isabel Schaukal for excellent technical assistance.

\section{References}

1. Mahley RW, Huang Y, Weisgraber KH. Putting cholesterol in its place: apoE and reverse cholesterol transport. J Clin Invest 2006;116:1226-9.

2. Vedhachalam C, Narayanaswami V, Neto N, Forte TM, Phillips MC, Lund-Katz S, et al. The C-terminal lipidbinding domain of apolipoprotein $\mathrm{E}$ is a highly efficient mediator of ABCA1-dependent cholesterol efflux that promotes the assembly of high-density lipoproteins. Biochemistry 2007;46:2583-93.

3. Kockx M, Rye KA, Gaus K, Quinn CM, Wright J, Sloane T, et al. Apolipoprotein A-I-stimulated apolipoprotein E 
secretion from human macrophages is independent of cholesterol efflux. J Biol Chem 2004;279:25966-77.

4. Matsuura F, Wang N, Chen W, Jiang XC, Tall AR. HDL from CETP-deficient subjects shows enhanced ability to promote cholesterol efflux from macrophages in an apoEand ABCG1-dependent pathway. J Clin Invest 2006;116: 1435-42.

5. Kaartinen M, Penttilä A, Kovanen PT. Mast cells of two types differing in neutral protease composition in the human aortic intima. Arterioscler Thromb 1994;14:96672.

6. Lindstedt L, Lee M, Kovanen PT. Chymase bound to heparin is resistant to its natural inhibitors and capable of proteolyzing high density lipoproteins in aortic intimal fluid. Atherosclerosis 2001;155:87-97.

7. Lindstedt KA, Leskinen MJ, Kovanen PT. Proteolysis of the pericellular matrix: a novel element determining cell survival and death in the pathogenesis of plaque erosion and rupture. Arterioscler Thromb Vasc Biol 2004;24:13508.

8. Lee-Rueckert M, Kovanen PT. Mast cell proteases: physiological tools to study functional significance of high density lipoproteins in the initiation of reverse cholesterol transport. Atherosclerosis 2006;189:8-18.

9. Huang Y, Liu XQ, Rall SC Jr, Taylor JM, von Eckardstein A, Assmann G, et al. Overexpression and accumulation of apolipoprotein $\mathrm{E}$ as a cause of hypertriglyceridemia. J Biol Chem 1998;273:26388-93.
10. Lee M, Kovanen PT, Tedeschi G, Oungre E, Franceschini G, Calabresi L. Apolipoprotein composition and particle size affect HDL degradation by chymase: effect on cellular cholesterol efflux. J Lipid Res 2003;44:539-46.

11. Huang $Y$, von Eckardstein A, Wu S, Assmann G. Effects of the apolipoprotein $E$ polymorphism on uptake and transfer of cell-derived cholesterol in plasma. J Clin Invest 1995;96:2693-701.

12. Lee $M$, von Eckardstein A, Lindstedt L, Assmann G, Kovanen PT. Depletion of preb 1 LpA1 and LpA4 particles by mast cell chymase reduces cholesterol efflux from macrophage foam cells induced by plasma. Arterioscler Thromb Vasc Biol 1999;19:1066-74.

13. Lee-Rueckert M, Vikstedt R, Metso J, Jauhiainen M, Kovanen PT. Association of cholesteryl ester transfer protein with HDL particles reduces its proteolytic inactivation by mast cell chymase. J Lipid Res 2007;Nov 8 [Epub ahead of print].

14. Eberini I, Gianazza E, Breghi L, Klugmann S, Calabresi L, Gomaraschi M, et al. Apolipoprotein A-I breakdown is induced by thrombolysis in coronary patients. Ann Med 2007;39:306-11.

15. Vaisar T, Pennathur S, Green PS, Gharib SA, Hoofnagle AN, Cheung MC, et al. Shotgun proteomics implicates protease inhibition and complement activation in the antiinflammatory properties of HDL. J Clin Invest 2007; $117: 746-56$. 